\title{
A matriz SWOT como ferramenta de análise para subsidiar a criação de consórcio intermunicipal na gestão e gerenciamento de Resíduos Sólidos Urbanos
}

\author{
The SWOT matrix as analysis tool to subsidize the creating an intercity consortium on gestating \\ and managing the Urban Solid Waste \\ La matriz SWOT como herramienta de análisis para subsidiar la creación de un consorcio \\ interurbano en la gestación y gestión de Residuos Sólidos Urbanos
}

\section{Resumo}

Esta pesquisa teve como objetivo utilizar a matriz SWOT como ferramenta de análise para subsidiar a possibilidade de criação de um consórcio intermunicipal na gestão e gerenciamento de Resíduos Sólidos Urbanos (RSU), na microrregião da Baixa Mogiana, Minas Gerais (MG). Foi realizado um levantamento bibliográfico, e o diagnóstico da região ocorreu a partir de pesquisa documental e pesquisa de campo. A partir destes resultados foi aplicada a técnica da matriz SWOT. Os resultados apontam que: a população concentrada na área urbana, com coleta de resíduo domiciliar, bem como a presença de catadores representam uma "força"; a ausência de Usina de Triagem e Compostagem (UTC), de um aterro sanitário, a presença de lixões e aterros controlados configuram entre as "fraquezas". Uma "ameaça" é o esvaziamento do consórcio durante a fase de implementação. A adoção de consórcio entre os municípios surge como "oportunidade" viável à medida em que alcança ganhos de escala por meio de medidas de caráter regional.

Palavras-chave: Desenvolvimento sustentável; Saneamento básico; Planejamento ambiental.

\begin{abstract}
This research had as purpose to use the SWOT matrix as an analysis tool to subsidize the possibility of creating an intercity consortium on gestating and managing the Urban Solid Waste (USW) on the Baixa Mogiana microregion, Minas Gerais (MG). It was made a bibliographic survey and the region diagnosys happened starting from documental research and field research. From these results, the SWOT matrix technique was applied. The results indicate that: the population concentrated in the urban area that has coverage of domestic waste collection, the region has collectors of reusable and recyclabe materials as a "force"; the absence of a Sorting and Composting Plant (SCP), sanitary landfill, as well as the presence of dumpgrounds and controlled landfills configure betwen the "weaknesses". One of the "threats" is the deflation of consorces during its planing or implementation phase. The adoption of consortiuns between municipalities comes as a viable "opportunity" as it reaches scale gains through regional measures.
\end{abstract}

Keywords: Sustainable development; Basic sanitation; Environmental planning.

\section{Resumen}

Esta investigación tuvo como objetivo utilizar la matriz SWOT como herramienta de análisis para apoyar la posibilidad de crear un consorcio intermunicipal en la gestión y gestión de Residuos Sólidos Urbanos (RSU), en la microrregión de Baixa Mogiana, Minas Gerais (MG). Se realizó un levantamiento bibliográfico y el diagnóstico de la región se realizó a partir de una investigación documental y de campo. A partir de estos resultados se aplicó la técnica matricial SWOT. Los resultados indican que: la población concentrada en la zona urbana, con recolección domiciliaria, así como la presencia de recolectores como "fuerza"; la ausencia de una Planta de Selección y Compostaje (PSC), de un relleno sanitario, la presencia de botaderos y rellenos controlados están entre las "debilidades". Una "amenaza" es el vaciamiento del consorcio durante la fase de implementación. La adopción de un consorcio entre municipios aparece como una "oportunidad" viable ya que logra ganancias de escala a través de medidas de carácter regional.

Palabras clave: Desenvolvimiento sustentable; Saneamiento; Planificación ambiental. 


\section{Introdução}

Fernandez (2004) indica que as alterações ambientais ocorrem por inúmeras causas, muitas naturais, e outras oriundas de intervenções antropológicas, consideradas não naturais. A cultura e um comportamento social consumistas têm contribuído para que essas alterações do ambiente se intensifiquem especialmente no ambiente urbano. Ribeiro e Morelli (2009) destacam que a atividade industrial mundial somada à ausência de programas eficazes de gestão fazem que cada vez mais resíduos sólidos sejam gerados, sem que haja uma correta destinação ou disposição destes, proporcionando um passivo ambiental, que compromete seu equilíbrio e a sadia qualidade de vida das pessoas.

Somando-se a esta afirmação, Quintana e Hacon (2011) explicam que nas sociedades industriais, em razão do elevado grau de desenvolvimento das forças produtivas e de um ritmo avassalador, há uma sobrecarga da natureza. Neste sentido, a busca crescente pelo lucro faz com que a produção de mercadorias seja sempre elevada e progressiva, o que gera uma elevada utilização dos recursos naturais em larga escala. Acrescenta-se a esta afirmação dos autores o grande volume de resíduos sólidos advindos deste comportamento predatório e irracional sobre os recursos naturais. Os resíduos sólidos constituem o que genericamente é denominado "lixo", considerados sem utilidade, supérfluos ou perigosos, gerados pela atividade humana, e que devem ser descartados ou eliminados.

A Lei Federal no 12.305/2010 (que instituiu a Política Nacional de Resíduos Sólidos - PNRS, e regulamentada pelo Decreto Federal no 7.404/2010), em seu art. 3º, inciso XVI, define resíduos sólidos como sendo:

Material, substância, objeto ou bem descartado resultante de atividades humanas em sociedade, a cuja destinação final se procede, se propõe proceder ou se está obrigado a proceder, nos estados sólido ou semissólido, bem como gases contidos em recipientes e líquidos cujas particularidades tornem inviável o seu lançamento na rede pública de esgotos ou em corpos d'água, ou exijam para isso soluções técnica ou economicamente inviáveis em face da melhor tecnologia disponível (Brasil, 2010a).

Os resíduos sólidos são potencialmente causadores de degradação da qualidade socioambiental por prejudicarem à saúde, contribuírem para a proliferação de pragas, poluição do solo, poluição atmosférica, poluição hídrica, poluição estética, entupimentos das redes de drenagem e enchentes. Estes resíduos podem ser classificados quanto a sua origem, ou seja, resíduos sólidos urbanos; resíduos industriais; resíduos de estabelecimentos comerciais e prestadores de serviços; resíduos dos serviços públicos de saneamento básico; resíduos de serviços de saúde; resíduos da construção civil; resíduos de serviços de transportes entre outros.

Neste trabalho, destacaremos apenas os Resíduos Sólidos Urbanos (RSU). Segundo a PNRS, art. 13, os RSU são aqueles que englobam os resíduos domiciliares (originários de atividades domésticas em residências urbanas); e resíduos de limpeza urbana (os originários da varrição, limpeza de logradouros e vias públicas e outros serviços de limpeza urbana) (Brasil, 2010a).

Segundo a Associação Brasileira de Empresas de Limpeza Pública e Resíduos Especiais - ABRELPE (2017), a população brasileira apresentou um crescimento de 0,75\% entre 2016 e 2017, enquanto a geração per capita de RSU apresentou aumento de $0,48 \%$. No entanto, a geração total de resíduos aumentou $1 \%$ no mesmo período, atingindo um total de 214.868 toneladas diárias de RSU no Brasil, ou seja 78,4 milhões de toneladas ano foram produzidas no Brasil (1,035 kg/hab/dia). A quantidade de RSU coletados em 2017 cresceu em todas as regiões em comparação a 2016, e a região Sudeste continua respondendo por cerca de $53 \%$ do total de resíduos coletados, apresentando o maior índice de cobertura da coleta de RSU do país (ABRELPE, 2017).

De uma forma geral, os municípios brasileiros tendem a implementar políticas públicas de forma isolada, a partir da elaboração do Plano Municipal de Gestão Integrada de Resíduos Sólidos - PMGIRS. No entanto, a adoção de consórcios 
(Planos Intermunicipais de Resíduos Sólidos), ou de outras formas de cooperação entre os entes federados, pode significar minimização da degradação ambiental, a elevação das escalas de aproveitamento dos RSU e a redução dos custos envolvidos nos processos de tratamento resíduos e disposição dos rejeitos. Além disso, a PNRS afirma que a priorização no acesso a recursos da União e aos incentivos ou financiamentos destinados a empreendimentos e serviços relacionados à gestão de resíduos sólidos ou à limpeza urbana e manejo de resíduos sólidos será dada mediante a elaboração do PMGIRS, que "optarem por soluções consorciadas intermunicipais", conforme estabelece o art. 18, inciso I.

Art. 18 A elaboração de plano municipal de gestão integrada de resíduos sólidos, nos termos previstos por esta Lei, é condição para o Distrito Federal e os Municípios terem acesso a recursos da União, ou por ela controlados, destinados a empreendimentos e serviços relacionados à limpeza urbana e ao manejo de resíduos sólidos, ou para serem beneficiados por incentivos ou financiamentos de entidades federais de crédito ou fomento para tal finalidade. $\S 1$ o. Serão priorizados no acesso aos recursos da União referidos no caput os Municípios que:

I - optarem por soluções consorciadas intermunicipais para a gestão dos resíduos sólidos, incluída a elaboração e implementação de plano intermunicipal, ou que se inserirem de forma voluntária nos planos microrregionais de resíduos sólidos referidos no $§ 11^{\circ}$ do art. 16 (Brasil, 2010a).

Cabe salientar que no estado de Minas Gerais, outra forma de obtenção de recursos é a aplicação da Lei Estadual no 18.030/2009, conhecida como Lei Robin Hood, que regulamenta o repasse de ICMS e garante um repasse financeiro aos municípios que realizarem tratamento e/ou disposição final de resíduos sólidos, com operação licenciada ou autorizada pelo órgão ambiental estadual (Minas Gerais, 2009).

Segundo Schneider et al. (2013), a gestão associada de serviços públicos, em especial os RSU pode envolver tanto o planejamento conjunto de determinadas políticas sem criar uma instância própria de execução de serviços, quanto compreender a delegação de funções de fiscalização e regulamentação de atividades realizadas pelos entes federativos consorciados. Neste mesmo sentido, Rates e Dallacosta (2018) afirmam que os consórcios públicos são apontados como uma ferramenta para gestão ambiental local, permitindo que os municípios formem uma estrutura institucional e profissional para realização destas atividades.

Além disso, os consórcios também podem servir de instrumentos de padronização de procedimentos realizados no licenciamento e na fiscalização ambiental sempre se pautando pelas Resoluções dos Conselhos Estaduais de Meio Ambiente, conforme preconizado na Lei Complementar Federal no 140/2011 (Brasil, 2011), propiciando ainda a uniformização da própria legislação e diminuindo as situações de conflito.

Conceitualmente, consórcios públicos baseiam-se na cooperação voluntária entre entes da Federação para atuação conjunta em assuntos de interesse comuns, conforme regulamentado pela Lei Federal no 11.107/2005, Lei de Consórcios Públicos - LCP (Brasil, 2005).

Batista (2011) neste contexto descreve a cooperação entre os entes federados por meio dos consórcios públicos, que ganham importância estratégica propiciando alternativas práticas e efetivas para encaminhar questões que em muitas oportunidades terão dificuldade em resolver no âmbito de atuação de uma única esfera da federação.

Segundo Rezende e Castor (2006), o planejamento estratégico municipal deve contemplar as ações e políticas cooperadas com os demais níveis federativos por dois motivos: primeiro pelo fato da solução dos problemas municipais não se circunscrever às competências típicas e exclusivas do município; e segundo, a enorme dependência financeira dos municípios em relação aos recursos estaduais e federais.

O art. 3o da Deliberação Normativa COPAM no 52/2001 orientou que a gestão de RSU utilize, preferencialmente, consórcios intermunicipais em vista de reduzir áreas para a disposição final de resíduos sólidos, bem como otimizar seu manejo e diminuição de gastos.

Art. 3o - Para fins de otimização do uso de áreas e redução dos custos de implantação e operação dos sistemas de 
disposição final de resíduos sólidos, as Prefeituras Municipais deverão dar prioridade à implementação de tais sistemas por meio da constituição de consórcios intermunicipais (Minas Gerais, 2001).

No tocante à disposição final dos RSU coletados, o panorama não registrou avanços em relação à 2016, mantendo praticamente a mesma proporção entre o que segue para locais adequados e inadequados com cerca de 42,3 milhões de toneladas de RSU, ou 59,1\% do coletado dispostos em aterros sanitários. O restante, que corresponde a 40,9\% dos resíduos coletados, foi despejado em locais inadequados por 3.352 municípios brasileiros, totalizando mais 29 milhões de toneladas de resíduos em lixões ou aterros controlados, que não possuem o conjunto de sistemas e medidas necessárias para proteção do meio ambiente contra danos e degradações com danos diretos à saúde de milhões de pessoas (ABRELPE, 2017).

De acordo com Monteiro (2001), o aterro sanitário é um método para disposição final dos RSU, sobre terreno natural, a partir do seu confinamento em camadas cobertas com material inerte, segundo normas operacionais específicas, de modo a evitar danos ao meio ambiente, em particular à saúde e à segurança pública. Portanto o aterro sanitário, planejado e construído observando normas operacionais específicas tem por objetivo evitar a poluição ambiental, bem como minimizar os impactos ambientais adversos resultantes do confinamento de rejeitos.

Memon (2010) afirma que a gestão de resíduos é um dos serviços públicos mais caros e que os países em desenvolvimento estão na pior situação para sua realização, pois dependem de tecnologias importadas de alto custo e possuem uma base de receita muito pequena. A situação ainda é mais drástica tratando-se de municípios pequenos, os quais apresentam ainda mais dificuldades quanto à falta de recursos, planejamento e capacidade técnica para a gestão de RSU.

Somando às afirmações de Schalch et al. (2002), Vilhena (2018) destaca a dificuldade do manejo de resíduos sólidos, devido a fatores como: limitações de ordem financeira - orçamentos inadequados, fluxos de caixa desequilibrados, tarifas desatualizadas, arrecadação insuficiente e inexistência de linhas de crédito específicas; deficiência na capacitação técnica e profissional, do gari ao engenheiro-chefe; descontinuidade política e administrativa; ausência de controle ambiental.

Nesse contexto, esta pesquisa tem objetivo de levantar elementos sobre o sistema de gestão e gerenciamento dos RSU dos municípios convenentes da Associação dos Municípios da Microrregião da Baixa Mogiana (AMOG), no estado de Minas Gerais, com o intuito de sugerir a adoção consorciada para os RSU.

\section{Metodologia}

Preliminarmente foi realizado um levantamento bibliográfico com propósito de reunir referências com informações técnico-científicos a respeito do tema da pesquisa. A escolha dos municípios ocorreu pelo fato dos mesmos estarem na mesma área (microrregião da Baixa Mogiana, MG) e serem convenentes a uma entidade de direito civil (AMOG).

A AMOG foi fundada em 08 de Janeiro de 1976, com dezessete (17) municípios mineiros associados: Alterosa, Arceburgo, Areado, Bom Jesus da Penha, Botelhos, Cabo Verde, Conceição Aparecida, Guaranésia, Guaxupé, Itamogi, Jacuí, Juruaia, Monte Belo, Monte Santo de Minas, Muzambinho, Nova Resende e São Pedro da União (Figura 1). É uma entidade de direito civil presidida por uma diretoria composta e eleita por prefeitos associados. Atua em regime de íntima cooperação com as autoridades congêneres e afins, bem como os órgãos Federais, Estaduais e Municipais, entidades privadas e mistas. Essa associação tem como objetivo ampliar e fortalecer a capacidade administrativa, econômica e social dos municípios, prestandolhes a assistência técnica, promovendo o estabelecimento de cooperação intermunicipal e intergovernamental e atuando em diversas áreas de interesse municipal, de acordo com os recursos financeiros repassados pelos municípios. 
Figura 1. Localização dos municípios convenentes da AMOG.

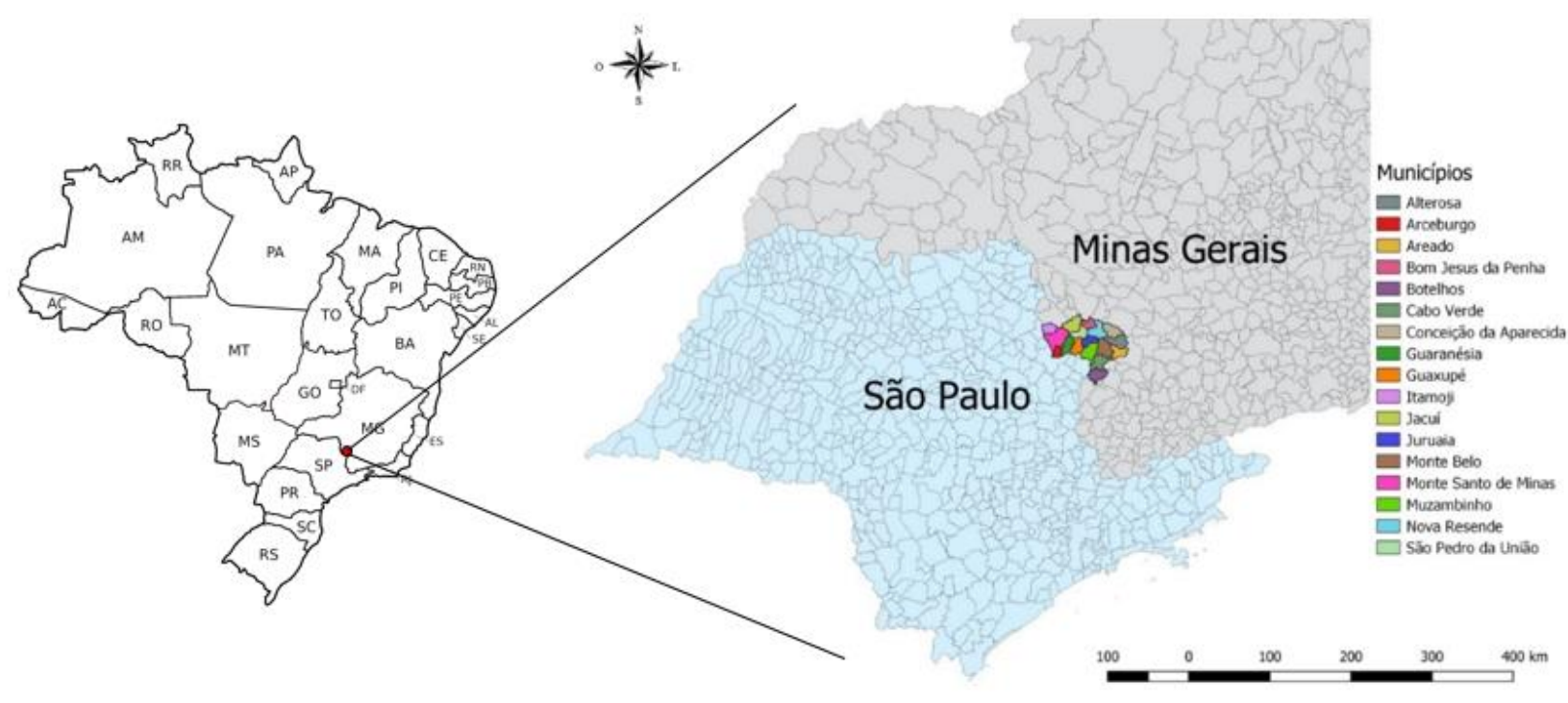

Fonte: Autores.

Os dezessete municípios pertencentes à AMOG apresentam uma área total de 5.584,542 Km2 e estão todos inseridos na mesorregião Sul/Sudeste de Minas (área de 49.523,893 Km2).

A pesquisa foi fundamentada em uma abordagem qualitativa de natureza teórico-empírica, que utiliza como método a pesquisa documental, ou seja, dados secundários. Os documentos foram consultados e analisados a partir dos sites das seguintes instituições (públicas e privadas): Instituto Brasileiro de Geografia e Estatística (IBGE); Sistema Nacional de Informações sobre a Gestão dos Resíduos Sólidos (SINIR); Sistema Nacional de Informações sobre Saneamento (SNIS); Empresa Brasileira de Pesquisa Agropecuária (EMBRAPA); Instituto Mineiro de Gestão das Águas (IGAM); Fundação Estadual do Meio Ambiente (FEAM); Secretaria de Estado do Meio Ambiente e Desenvolvimento Sustentável de Minas Gerais (SEMAD); Conselho Estadual de Política Ambiental (COPAM); Superintendência Regional de Regularização Ambiental do Sul de Minas (SUPRAM SM); Associação Brasileira de Empresas de Limpeza Pública e Resíduos Especiais (ABRELPE); Compromisso Empresarial para Reciclagem (CEMPRE); e Confederação Nacional de Municípios (CNM). Nesta etapa também ocorreu a pesquisa de campo em todos os municípios convenentes da AMOG com objetivo confrontar a pesquisa documental com a realidade.

Em seguida, aplicou-se a técnica da matriz SWOT como ferramenta de análise para auxiliar o planejamento e tomada de decisão quanto à possibilidade de criação de um consórcio intermunicipal na gestão e gerenciamento de RSU dos municípios convenentes da AMOG. A matriz SWOT é uma técnica utilizada para analisar a gestão e o planejamento de empresas, seja ela de pequeno ou grande porte (Wright et al., 2010; Maximiano, 2011; Fernandes et al., 2013; Daft, 2015). No entanto, atualmente ela vem sendo utilizada nas mais variadas atividades das organizações públicas, inclusive no planejamento dos municípios.

Rezende e Castor (2006) afirmam que a análise das "forças" e "fraquezas" municipais pode ser feita através da matriz SWOT, utilizada para elaborar o diagnóstico de cidades. Esta matriz descreve as "oportunidades" e as "ameaças" ou riscos como componentes do ambiente externo. As "forças" ou pontos fortes são as variáveis internas e controláveis, que propiciam condições favoráveis para o município e podem influenciar positivamente o seu desenvolvimento. As "fraquezas" ou pontos fracos são variáveis internas e controláveis que propiciam condições desfavoráveis para o município e podem influenciar negativamente o seu desenvolvimento. Já o ambiente externo as "oportunidades" e "ameaças" são variáveis incontroladas e normalmente imprevisíveis pelo município. Sendo que as "oportunidades" são aspectos positivos que podem favorecer a 
competitividade e o crescimento e as "ameaças" o município precisa reagir para evitá-las ou mesmo neutralizá-las, pois as mesmas podem impactar negativamente o crescimento e o desenvolvimento econômico, social e ambiental dos municípios.

A partir dessas análises foram feitas sugestões e indicações sobre as possibilidades de gestão e gerenciamento de RSU em um sistema consorciado dos dezessete municípios que fazem parte da microrregião da Baixa Mogiana.

\section{Resultados e Discussão}

A figura abaixo representa a situação dos municípios que integram a AMOG, sendo que a maioria ainda encontra-se com lixões e aterros controlados, trazendo desta forma riscos para o equilíbrio ambiental e a sadia qualidade de vida (Figura 2).

Figura 2. Situações das destinações (ou disposições) finais dos resíduos (ou rejeitos) dos RSU nos municípios da AMOG em 2016.
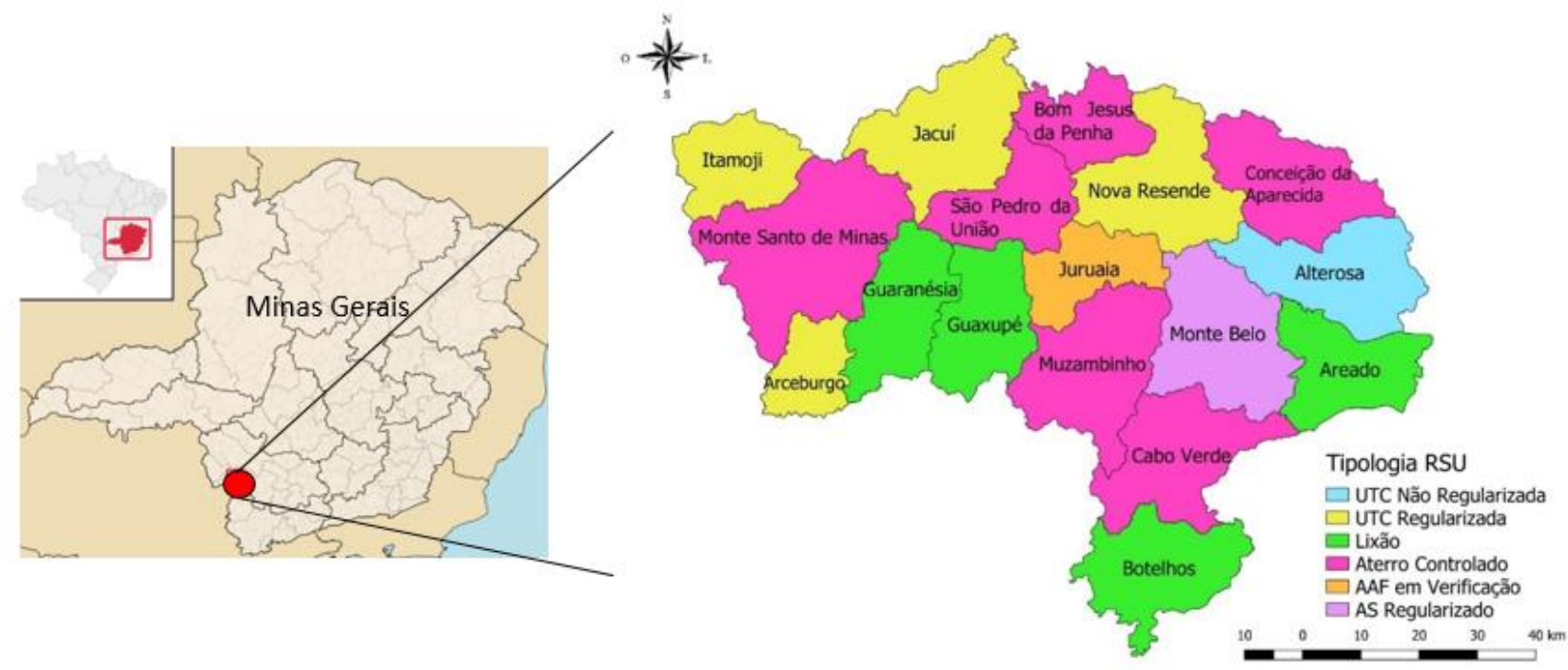

AAF - Autorização Ambiental de Funcionamento; AS - Aterro Sanitário; UTC - Usina de Triagem e Compostagem. Fonte: Adaptado da FEAM (2016).

Conforme observado na figura anterior, quatro municípios apresentam lixões (Areado, Botelhos, Guaranésia e Guaxupé); seis, aterros controlados (Bom Jesus da Penha, Cabo Verde, Conceição da Aparecida, Monte Santo de Minas, Muzambinho e São Pedro da União); cinco apresentam Usina de Triagem e Compostagem (UTC) (Alterosa, Arceburgo, Itamogi, Jacuí e Nova Resende) com rejeitos indo para aterro controlado; um apresenta autorização ambiental de funcionamento de UTC e aterro controlado (Juruaia); e um, que envia seu RSU para o aterro sanitário de Alfenas, empresa privada (Monte Belo).

Os problemas ambientais e a saúde humana poderiam ser solucionados, entre outras medidas, se houvesse maior fiscalização na disposição final dos RSU dos municípios, incentivo à formação de cooperativas de catadores e um aterro sanitário nos locais. Porém em se tratando de municípios de pequeno porte, em sua quase totalidade, a construção de um aterro por município torna-se inviável economicamente. Outra possível solução para diminuir a quantidade de RSU seria a implantação de UTC nos municípios que ainda não tem. Dos municípios pesquisados, apenas seis apresentam UTC: Alterosa, Arceburgo, Itamogi, Jacuí, Juruaia e Nova Resende.

As UTC apresentam várias vantagens, destacando-se: a ambiental, pelo aumento de vida útil de um aterro sanitário, reciclagem e compostagem, o que resulta em menos rejeito; e a econômico/social (geração de emprego e renda). Programas e políticas públicas (como por exemplo, de Educação Ambiental) envolvendo a segregação nas residências, bem como as coletas seletivas potencializam as UTC e precisam estar presentes em todos os municípios. 
A seguir são apresentados número de habitantes, quantidade média total de RSU gerados e áreas (municipal e urbana) dos municípios convenentes da AMOG (Tabela 1).

Tabela 1. Municípios da AMOG, população, quantidade de RSU e áreas (Municipal e urbana).

\begin{tabular}{|c|c|c|c|c|}
\hline Municípios & $\begin{array}{c}\text { População } \\
\text { (habitantes) } \\
\text { Ano 2014* } \\
\end{array}$ & $\begin{array}{c}\text { Quantidade média total de } \\
\text { RSU (t/dia) } \\
\text { Ano 2014* } \\
\end{array}$ & $\begin{array}{c}\text { Área do município } \\
\left(\mathrm{Km}^{2}\right) \\
\text { Ano 2015** } \\
\end{array}$ & $\begin{array}{l}\text { Área urbana } \\
\left(\mathbf{K m}^{2}\right) \\
\text { Ano 2015*** }\end{array}$ \\
\hline Guaxupé & 51.704 & 25,85 & 286,398 & 20,342 \\
\hline Muzambinho & 21.012 & 10,5 & 409,948 & 5,458 \\
\hline Monte Santo de Minas & 21.234 & 10,0 & 594,632 & 6,19 \\
\hline Guaranésia & 19.319 & 9,6 & 294,828 & 5,663 \\
\hline Nova Resende & 16.313 & 8,16 & 390,152 & 5,584 \\
\hline Itamogi & 11.472 & 7,63 & 243,735 & 2,529 \\
\hline Botelhos & 15.325 & 7,6 & 334,089 & 6,777 \\
\hline Areado & 14.624 & 7,3 & 283,124 & 3,653 \\
\hline Alterosa & 14.371 & 7,18 & 362,01 & 3,375 \\
\hline Cabo Verde & 14.280 & 7,13 & 368,206 & 1,603 \\
\hline Monte Belo & 13.440 & 6,7 & 421,283 & 3,039 \\
\hline Arceburgo & 10.262 & 5,13 & 162,875 & 3,318 \\
\hline Conceição da Aparecida & 10.263 & 5,13 & 352,521 & 2,262 \\
\hline Juruaia & 10.008 & 5,0 & 220,353 & 2,056 \\
\hline Jacuí & 7.770 & 3,88 & 409,229 & 1,602 \\
\hline São Pedro da União & 5.016 & 2,5 & 260,827 & 1,272 \\
\hline Bom Jesus da Penha & 4.121 & 2,06 & 208,349 & 0,915 \\
\hline Total & 260.534 & 131,35 & $5.602,559$ & 75,638 \\
\hline
\end{tabular}

Fonte: Adaptado de IBGE (2018)**, FEAM (2016)* e EMBRAPA (2015)***

Diante dos dados apresentados na Tabela 1, nota-se que a maioria dos municípios são de pequeno porte (população inferior a 20.000 habitantes) e por este motivo torna-se elevado o custo para cada administração pública implementar aterros sanitários para a disposição final ambientalmente adequada. A quantidade média de RSU por habitante dos municípios é de 0,508 $\mathrm{kg} / \mathrm{hab} /$ dia. Esse valor poderá ser reduzido se ocorrerem trabalhos efetivos de Educação Ambiental (EA), bem como diminuição de consumo exagerado, no entanto poderá aumentar caso o poder aquisitivo da população melhore, o consumo de descartáveis aumente e a EA não seja efetiva. Ou ainda ficar estagnado.

A Deliberação Normativa COPAM no 170/2011 (Minas Gerais, 2011) estipulava uma data (até setembro de 2014) para que os municípios de Minas Gerais elaborassem seu respectivo Plano de Resíduos Sólidos (podendo ser Plano Municipal de Gestão Integrada de Resíduos Sólidos - PMGIRS ou Plano Simplificado de Gestão Integrada de Resíduos Sólidos PSGIRS, dependendo do número de habitantes). A dispensa do plano poderia ocorrer para aqueles municípios que tivessem elaborado o Plano Municipal de Saneamento Básico - PMSB - com conteúdo mínimo abrangendo os serviços de limpeza pública e manejo de resíduos sólidos previsto na PNRS; ou se o município tivesse optado por "soluções consorciadas intermunicipais" para a gestão dos resíduos sólidos, assegurando que o plano intermunicipal preenchesse os requisitos estabelecidos nos incisos na PNRS (Brasil, 2010a). Conforme levantado, dez municípios entre os dezessete estão em acordo com os dispositivos legais (Deliberação Normativa COPAM no 170/2011 e a Lei Federal no 12.305/2010). No entanto, já se passaram mais de 5 anos do prazo limite e sete municípios (Guaranésia, Botelhos, Areado, Conceição da Aparecida, Arceburgo, Juruaia e Bom Jesus da Penha) não o fizeram, os quais apresentam condições desfavoráveis no acesso a recursos (da União ou por ela controlados) destinados a empreendimentos e serviços relacionados à limpeza urbana e ao manejo de resíduos sólidos, ou para serem beneficiados por incentivos ou financiamentos de entidades federais de crédito ou fomento para tal finalidade (Tabela 2). 
Tabela 2. Relação dos municípios da AMOG que cumpriram ou não a Deliberação Normativa COPAM nº 170/2011 (Lei Federal no 11.445/2007 e Lei Federal no 12.305/2010).

\begin{tabular}{|c|c|c|c|c|c|}
\hline Municípios & $\begin{array}{c}\text { O município possui } \\
\text { Plano Municipal de } \\
\text { Saneamento } \\
\text { Básico, conforme a } \\
\text { Lei no } 11.445 / 2007 ?\end{array}$ & $\begin{array}{c}\text { O Plano Municipal de } \\
\text { Saneamento Básico } \\
\text { abrange os serviços de } \\
\text { Limpeza pública e manejo } \\
\text { de resíduos sólidos? }\end{array}$ & $\begin{array}{l}\text { O município faz } \\
\text { parte de } \\
\text { consórcio público } \\
\text { na área de } \\
\text { saneamento? } \\
\end{array}$ & $\begin{array}{c}\text { O município possui } \\
\text { Plano de Gestão } \\
\text { Integrada de Resíduos } \\
\text { Sólidos, conforme a Lei } \\
\text { no } 12.305 / 2010 ?\end{array}$ & $\begin{array}{c}\text { O município } \\
\text { faz parte de } \\
\text { consórcio na } \\
\text { área resíduos } \\
\text { sólidos? } \\
\end{array}$ \\
\hline Guaxupé & Não* & Não** & Não** & Sim* & Não** \\
\hline Monte Santo de Minas & Não* & Não** & Não** & Sim* & Não*** \\
\hline Muzambinho & Não* & Não** & Não** & Sim* & Não*** \\
\hline Guaranésia & Não* & Não** & Não** & Não* & Não** \\
\hline Nova Resende & Não** & Não** & Não** & Sim** & Não** \\
\hline Botelhos & Não* & Não** & Não** & Não* & Não** \\
\hline Cabo Verde & Sim* & Não*** & Não** & Sim* & Não*** \\
\hline Areado & Não** & Não** & Não** & Não*** & Não*** \\
\hline Alterosa & Não** & Não*** & Não** & Sim** & Não*** \\
\hline Monte Belo & Sim** & Sim** & Não** & Não** & Não** \\
\hline Itamogi & Não* & Não** & Não** & Sim* & Não** \\
\hline $\begin{array}{c}\text { Conceição da } \\
\text { Aparecida }\end{array}$ & Não* & Não** & Não** & Não* & Não** \\
\hline Arceburgo & Não* & Não** & Não** & Não* & Não** \\
\hline Juruaia & Não** & Não*** & Não** & Não*** & Não*** \\
\hline Jacuí & Não* & Não** & Não** & Sim* & Não** \\
\hline São Pedro da União & Não* & Não** & Não** & Sim* & Não** \\
\hline Bom Jesus da Penha & Não*** & Não*** & Não** & Não*** & Não*** \\
\hline
\end{tabular}

Fontes: Adaptado de SNIS (2017)* e IBGE (2017)***

É preocupante a maioria dos municípios não apresentar um Plano Municipal de Saneamento Básico, já que o mesmo está diretamente relacionado à prestação de serviços públicos essenciais à população, como: abastecimento de água, esgotamento sanitário, limpeza urbana e manejo dos resíduos sólidos realizados de forma adequada à saúde pública e à proteção do meio ambiente. Apenas Cabo Verde e Monte Belo apresentam o PMSB, sendo que este último município abrangeu em seu plano os serviços de limpeza pública e manejo de resíduos sólidos.

Especificamente em relação ao Plano Municipal de Gestão Integrada de Resíduos Sólidos (PMGIRS), muitos municípios deixam de fazer alegando gastos na elaboração deste instrumento. No entanto, muitas prefeituras têm utilizado seu corpo técnico (concursados e de cargos comissionados ou de confiança) para fazê-lo. Existem atualmente vários órgãos públicos, entre eles a própria FEAM, que tem prestado consultoria para regularização de situações relacionadas ao RSU e mais amplamente sobre o PMGIRS. Além disso, em se tratando de municípios de porte pequeno (Guaranésia, Botelhos, Areado, Monte Belo, Conceição da Aparecida, Arceburgo, Juruaia e Bom Jesus da Penha), o plano municipal de gestão integrada de resíduos sólidos poderá ser feito com conteúdo simplificado conforme estabelece a PNRS.

Interessante ainda destacar que Monte Belo está levando seus RSU para o Aterro de Alfenas, e Arceburgo tem uma empresa privada que realiza o tratamento e a disposição final dos RSU, o que não justifica esses municípios deixarem de elaborar seu PMGIRS. O PMGIRS é mais genérico e integrador em relação a origem de todos os resíduos gerados, assim é obrigação de todos os municípios elaborá-lo.

Até o presente momento não há um Plano de Gestão Integrada de Resíduos Sólidos (PGIRS) de forma unificada para consórcios intermunicipais que integram a AMOG.

Em relação à coleta seletiva, foi constatado que apenas sete municípios abasteceram dados para o SNIS (período 2013 à 2017) e informaram realizar a coleta seletiva, bem como sobre a taxa (\%) de cobertura da coleta seletiva porta-a-porta em relação a população urbana dos municípios (Guaxupé, Monte Santo de Minas, Nova Resende, Botelhos, Itamogi, Jacuí e São Pedro da União). Segundo os dados levantados e levando em consideração a área urbana dos municípios pode-se afirmar que a coleta seletiva porta-a-porta chega a $23,045 \mathrm{~km}^{2}$, ou seja, a 30,46\% de toda área urbana da região. A baixa taxa de coleta seletiva indica maior quantidade de resíduos, que poderiam evitar serem levados à disposição final e caracterizados como 
rejeitos. Além disso, uma baixa taxa de cobertura de coleta seletiva pode enfraquecer social e economicamente as cooperativas ou outras formas de associação de catadores formadas por pessoas físicas geralmente constituída de baixa renda.

Segundo SNIS (2017), existem apenas três associações de catadores de materiais reutilizáveis e recicláveis na região (Guaxupé, Monte Santo de Minas e Cabo Verde). É indissociável da função ambiental, econômica e social, o fato dos catadores de materiais reutilizáveis e recicláveis estarem organizados nas cidades. A partir de suas ações evita-se a exploração de recursos naturais como matéria prima; economiza-se energia no reprocessamento de materiais, se comparado com a extração e produção de matérias-primas in natura; além disso economiza-se também na coleta, disposição final de rejeitos, e por consequência reduzem-se os impactos ambientais negativos.

Segundo dados do SNIS (2014 à 2017), a despesa média per capita com RSU (R\$/habitante) dos municípios convenentes da microrregião da Baixa Mogiana é de R \$ 58,35, destaque para os municípios de Guaxupé, Guaranésia, Nova Resende, Itamogi, Arceburgo e Juruaia que ficaram acima da média. Os municípios de Areado, Monte Belo e Bom Jesus da Penha não fazem parte desta análise porque não declararam informações juntos ao SNIS neste período. A média da receita arrecadada per capita é de R \$16,03, sendo que Guaxupé, Cabo Verde, Itamogi, Arceburgo e São Pedro da União ficam acima desta média. Muzambinho, Nova Resende e Conceição da Aparecida não apresentaram dados neste período segundo SNIS (Figura 3).

Figura 3. Despesa e receita média arrecadada per capita com serviços de manejo do RSU (R $\$ /$ habitante) entre os períodos 2014 à 2017.

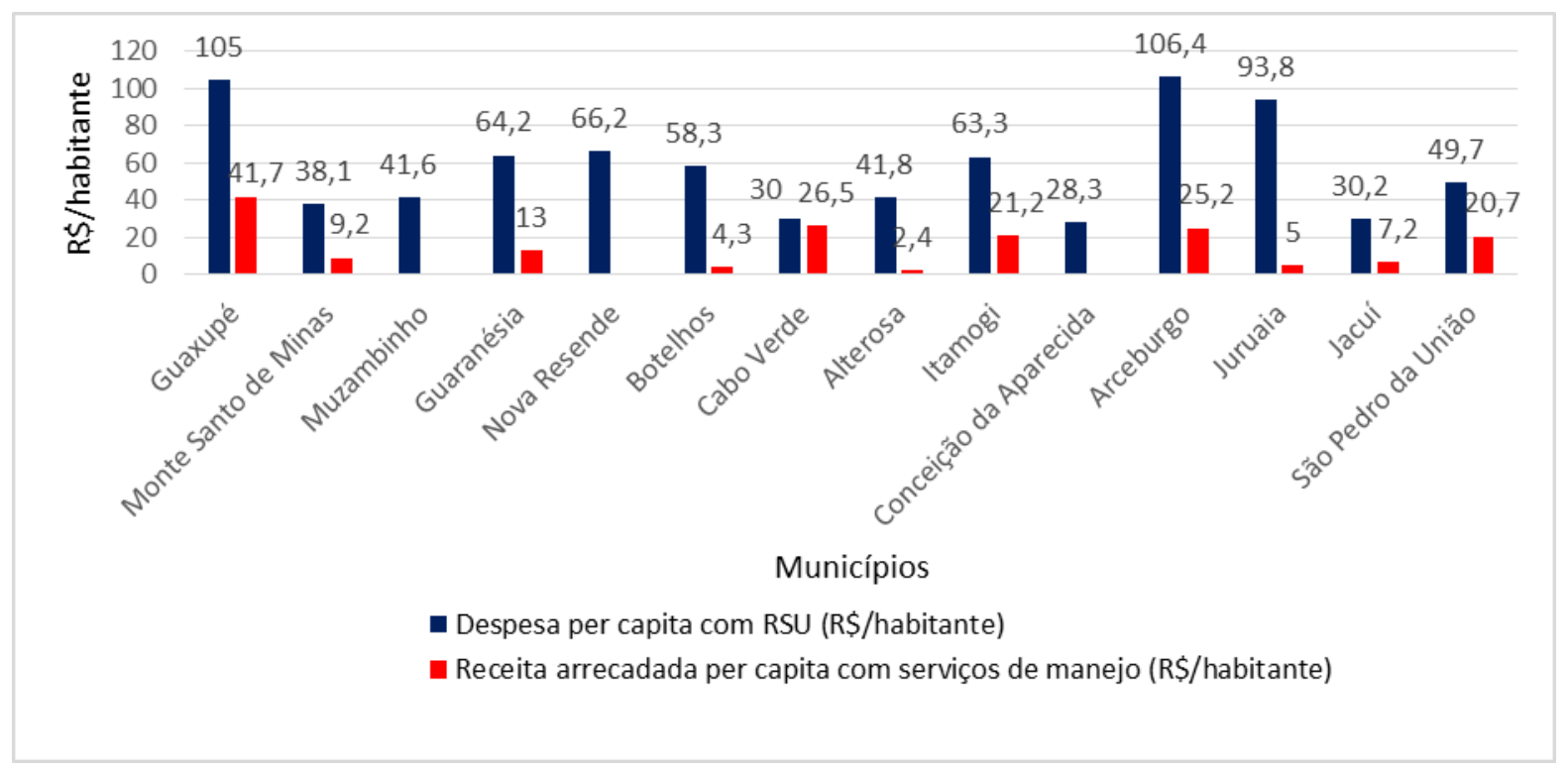

Fonte: Adaptado de SNIS (2017).

Considerando a despesa e a receita arrecadada média per capita com serviços de manejo do RSU (R $\$$ habitante), pode-se afirmar que nenhum município que informou o SNIS (períodos 2014 à 2017), apresenta recursos arrecadados que venham a cobrir as suas despesas, ou seja, os municípios evidenciam uma fragilidade da sustentabilidade financeira. Os municípios de Areado, Monte Belo e Bom Jesus da Penha não fazem parte desta análise porque não declararam informações juntos ao SNIS neste período.

Em relação a incidência média de despesas sobre RSU desses municípios entre os períodos 2014 à 2017, esta foi de 2,86\% (Figura 4). 
Figura 4. Incidência média de despesas sobre RSU dos municípios convenentes da AMOG, entre os períodos 2014 à 2017.

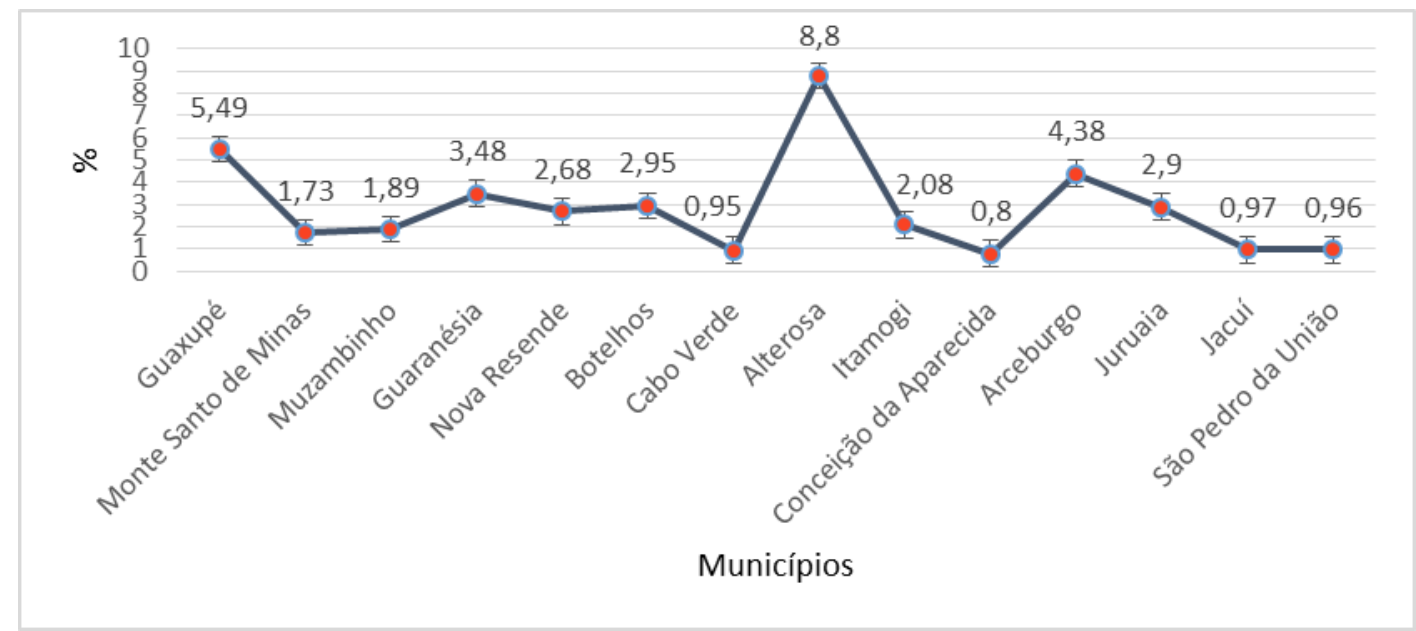

Fonte: Adaptado de SNIS (2017).

É um valor muito baixo, considerando a importância do tema e as consequências que o mau gerenciamento dos RSU podem provocar para o ambiente e para a saúde da população. Os serviços de manejo dos resíduos sólidos exercem um forte impacto no orçamento das administrações municipais, podendo atingir 20\% dos gastos da municipalidade (IBGE, 2008), bem diferente da média 2,86\% apresentada. Os municípios de Areado, Monte Belo e Bom Jesus da Penha não fazem parte desta análise porque não declararam informações juntos ao SNIS neste período.

A partir deste momento, foi construída a matriz SWOT e sua análise poderá auxiliar o planejamento e tomada de decisão quanto à possibilidade de criação de um consórcio intermunicipal na gestão e gerenciamento de RSU dos municípios convenentes da AMOG (Quadro 1). 
Quadro 1. Matriz SWOT para a gestão de RSU para os municípios convenentes da AMOG. Ambiente interno.

\begin{tabular}{|c|c|c|}
\hline & Fatores positivos & Fatores negativos \\
\hline 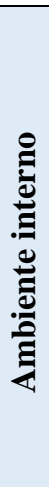 & $\begin{array}{l}\text { Forças } \\
\text { - Presença da AMOG. } \\
\text { - Presença de setores de engenharia na AMOG. } \\
\text { - Treinamento e capacitação técnica por intermédio da AMOG. } \\
\text { - Proximidade entre os municípios, em especial para localização } \\
\text { do Aterro Sanitário. } \\
\text { - Presença do Conselho Municipal de Meio Ambiente ou similar } \\
\text { na maioria dos municípios. } \\
\text { - Municípios de pequeno porte, o que facilita a implantação de } \\
\text { ações, projetos e políticas públicas. } \\
\text { - População concentrada na área urbana. } \\
\text { - Cobertura majoritária de coleta de resíduo domiciliar } \\
\text { (RDO/população urbana). } \\
\text { - Presença de catadores de materiais reutilizáveis e recicláveis } \\
\text { (informais na sua maioria). }\end{array}$ & $\begin{array}{l}\text { Fraquezas } \\
\text { - Predomínio de lixões e aterros controlados. } \\
\text { - Ausência de aterro sanitário na microrregião. } \\
\text { - Ausência, em grande parte dos municípios, de um órgão exclusivo de meio } \\
\text { ambiente. } \\
\text { - Ausência de Conselhos Municipais de Resíduos Sólidos. } \\
\text { - Ausência de um Conselho Regional de Resíduos Sólidos. } \\
\text { - Grande parte dos municípios não apresenta legislações ou instrumentos de } \\
\text { gestão ambiental (Leis Orgânicas, Planos Diretores, Códigos Ambientais etc) } \\
\text { sobre saneamento básico; e coleta seletiva de resíduo domiciliar (RDO). } \\
\text { - Maioria não tem um Plano Municipal de Saneamento Básico (PMSB). } \\
\text { - Praticamente metade dos municípios não possui Planos de Gestão Integrada de } \\
\text { Resíduos Sólidos. } \\
\text { - Maioria dos municípios não tem coleta seletiva de RDO. } \\
\text { - Baixa taxa de cobertura de coleta seletiva. }\end{array}$ \\
\hline
\end{tabular}

\begin{tabular}{|c|c|c|}
\hline 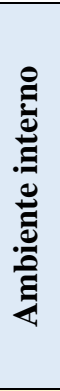 & $\begin{array}{l}\text { Forças (Continuação) } \\
\text { - Presença de três associações de catadores de materiais } \\
\text { reutilizáveis e recicláveis. } \\
\text { - Vocação agrícola para absorver compostos orgânicos da } \\
\text { compostagem. } \\
\text { - Desenvolvimento de mercado, produção e o consumo de } \\
\text { produtos derivados de materiais reciclados e recicláveis na } \\
\text { região. } \\
\text { - Localização geográfica (entre os estados de São Paulo e Minas } \\
\text { Gerais) com rodovias asfálticas de boa qualidade. } \\
\text { - Parceria entre instituições de ensino superior públicas e } \\
\text { privadas. }\end{array}$ & $\begin{array}{l}\text { Fraquezas (Continuação) } \\
\text { - Baixa taxa de cobertura de coleta seletiva. } \\
\text { - Poucos municípios apresentam Usina de Triagem e Compostagem (UTC). } \\
\text { - Praticamente metade dos municípios apenas possuem órgãos responsáveis pela } \\
\text { regulação de serviços de manejo de resíduos sólidos. } \\
\text { - Ausência de políticas públicas regionais de Educação Ambiental na área de } \\
\text { Resíduos Sólidos Urbanos (RSU). } \\
\text { - Com exceção de Alterosa e Botelhos, nenhum outro município apresenta } \\
\text { programas implementados pelo governo municipal em parceria com o Governo } \\
\text { Federal sobre Educação Ambiental. } \\
\text { - Ausência, em nível regional, de acordos setoriais e termos de compromisso } \\
\text { firmados entre o poder público e o setor empresarial. }\end{array}$ \\
\hline 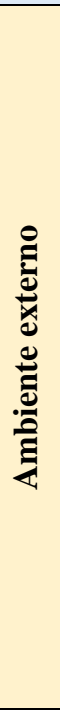 & $\begin{array}{l}\text { Oportunidade } \\
\text { - Prioridade no acesso aos recursos da União para os municípios } \\
\text { que optarem por "soluções consorciadas intermunicipais" para a } \\
\text { gestão dos RSU. } \\
\text { - Prioridade de recursos para outros serviços de Saneamento } \\
\text { Básico (União e Estado). } \\
\text { - Incentivo na aplicação da Lei Robin Hood com repasse de } \\
\text { ICMS para os municípios que realizarem o tratamento e/ou } \\
\text { disposição de resíduos sólidos. } \\
\text { - Proximidade da mesorregião Sul/Sudeste de Minas com as } \\
\text { grandes metrópoles (Belo Horizonte, MG e São Paulo, SP). } \\
\text { - Estradas de rodagem asfáltica em boas condições para } \\
\text { escoamento de seus produtos. } \\
\text { - Presença de empresas recicladoras no seu entorno. } \\
\text { - Disputa de mercado para consumo de produtos derivados de } \\
\text { materiais reciclados e recicláveis no entorno. Possibilidade de } \\
\text { comercialização e obtenção de melhores preços. } \\
\text { - Crescente mercado de compostos orgânicos. } \\
\text { - Parceria entre instituições de ensino superior públicas e } \\
\text { privadas de outras regiões. } \\
\text { - Possibilidade de atração de investimentos e empresas para } \\
\text { microrregião. }\end{array}$ & $\begin{array}{l}\text { Ameaças } \\
\text { - Esvaziamento de municípios na microrregião da Baixa Mogiana. Perda de } \\
\text { municípios convenentes da AMOG para outras associações (ou consórcios). } \\
\text { - Terceirização ou não de serviços para destinação e disposição de RSU para } \\
\text { outros municípios fora da microrregião da Baixa Mogiana. } \\
\text { - Concorrências com empresas e catadores autônomos que compram os materiais } \\
\text { recicláveis e reutilizáveis. }\end{array}$ \\
\hline
\end{tabular}

Fonte: Autores.

No ambiente interno, a presença da AMOG (Associação dos Municípios da Microrregião da Baixa Mogiana) é uma "força" à medida que aglutina representantes dos municípios e permite a busca de soluções conjuntas, bem como alinhamento de políticas públicas ambientais na microrregião.

A AMOG pode ser o grande articulador político na propositura de um plano estratégico de RSU entre os municípios convenentes, bem como para a criação do consórcio intermunicipal. A formação de um comitê de planejamento de ações na região torna-se fundamental, a fim de organizar as reuniões e discussões sobre os RSU. Sugere-se que tal comitê seja composto por um número de membros (a ser definido em assembleia), com direito a voz e voto, divididos em 4 (quatro) segmentos (quadripartite): representantes do Estado; representantes dos municípios; representantes de entidades civis legalmente constituídas; e representantes de entidades civis de catadores de materiais reutilizáveis e recicláveis legalmente constituídos. Nesta composição do comitê é importante que haja 50\% de representantes do poder público e 50\% entidades civis, garantindo 
assim a paridade e o equilíbrio de forças em matéria de voz e decisão.

É necessário também que audiências e assembleias públicas dos municípios convenentes da AMOG sejam realizadas, para discussão e aprovação do estatuto e do protocolo de intenções para a gestão e gerenciamento consorciado de RSU. A audiência pública tem por objetivo expor à sociedade o conteúdo, dirimindo dúvidas e recolhendo dos presentes as críticas e sugestões a respeito tanto do estatuto como do Protocolo de Intenções.

O acordo celebrado no Protocolo de Intenções entre os poderes executivos de cada ente a se consorciar deverá ser ratificado pelas respectivas casas legislativas. Enfim, seguir todos os critérios estabelecidos nas normas, em especial a Lei Federal no 11.107/2005, que disciplina a contratação de consórcios públicos.

A partir do estabelecimento de consórcio, espera-se que as diferenças político-partidárias isoladas de cada ente municipal diminuam em prol de objetivos coletivos e solidários.

Além disso, a AMOG através de seus setores de engenharia poderá auxiliar na capacitação técnica e assessorar as instalações de UTC nos municípios que ainda não possuem; na construção de um aterro sanitário para recebimento dos rejeitos dos municípios convenentes, e consequentemente eliminação dos lixões e aterros controlados existentes na região.

A ausência de consórcios intermunicipais, a ausência de UTC na maioria dos municípios, a ausência de um aterro sanitário e a presença de lixões e aterros controlados configuram entre as "fraquezas" que podem ser superadas. A construção de um aterro sanitário atendendo todos os municípios de forma consorciada, a fim de receber todos os rejeitos da municipalidade resolveria o problema causado pelos lixões e aterros controlados. Outro ponto que converge para a construção de um aterro sanitário é a proximidade entre os municípios ("força"), pois pequenas distâncias garantem economia no transporte de rejeitos, por exemplo.

Em razão de toda configuração dos municípios, sugere-se que cada um tenha uma UTC, bem como que encaminhem seus rejeitos a um aterro sanitário. Este poderá ser construído em Guaxupé, por ser o município mais populoso, apresentar malha viária que interliga as várias localidades na região (menor distância), maior gerador de RSU, bem como está próximo de outros grandes geradores (Muzambinho, Monte Santo de Minas, Guaranésia, Nova Resende, Itamogi e Botelhos). Estes municípios produzem juntos cerca de 79 t/dia, ou seja próximo a 60\% de todo RSU produzido.

A seguir as rodovias asfálticas que interligam os municípios, as UTC presentes na microrregião e possível localização do aterro sanitário (Figura 5).

Figura 5. Rodovias asfálticas que interligam os municípios, as UTC presentes na microrregião e possível localização do aterro sanitário.

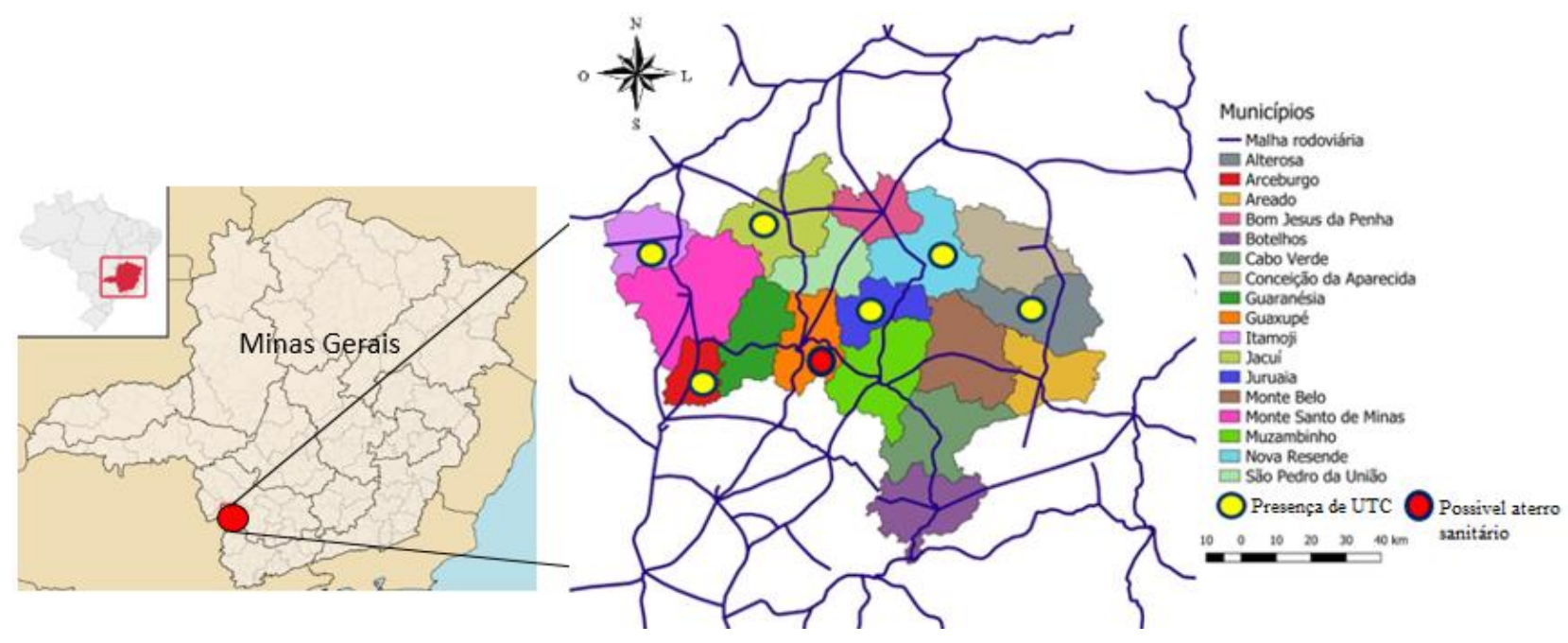

Fonte: Autores. 
$\mathrm{Na}$ figura acima, quatro municípios estão localizados próximos ao município onde é sugerida a construção do aterro sanitário, Guaxupé (Muzambinho, Guaranésia, Juruaia e São Pedro da União), não apresentando assim dificuldades para transportar os rejeitos de seus municípios. No entanto, o restante dos municípios apresenta distâncias maiores, e conforme já descrito neste trabalho, Tchobanoglous et al. (1993) afirmam que distância superior a $24 \mathrm{~km}$ entre o ponto de coleta e o local de disposição final tem implicações econômicas, podendo ser usadas as estações de transbordo. Esta resolução poderá ser definida pelo Conselho Regional de Resíduos Sólidos, a ser criado. A população concentrada na área urbana e com cobertura de coleta de resíduo domiciliar (RDO/população urbana) de 99,34\% são "forças" que facilitam ações de coleta seletiva. No entanto, configura-se entre as "fraquezas" a coleta seletiva pelo fato da maioria dos municípios não realizarem, e os que realizam possuem baixa taxa de cobertura.

A ausência de indicadores para acompanhamento das experiências de coleta seletiva é um ponto "fraco", que poderá ser resolvido a partir da criação de cooperativas (ou outra forma de associação), ou através de um órgão público da prefeitura (Secretaria de Meio ambiente ou da Promoção Social). Aproximadamente metade (47\%) desses municípios possuem órgãos responsáveis pela regulação de serviços de manejo de resíduos sólidos. Poderia ser atribuição destes órgãos o acompanhamento e a produção de indicadores de coleta seletiva. Nem todos os municípios têm órgão regulador de serviços de manejo de resíduos sólidos, por este motivo representa "fraqueza", assim, orienta-se os municípios para que realizem a sua criação.

A falta de políticas públicas envolvendo os catadores contribui para tal "fraqueza". O poder público precisa reconhecer o grande serviço prestado pelos catadores e incentivar a criação e o desenvolvimento de cooperativas ou de outras formas de associação, bem como a sua integração nas ações que envolvam a responsabilidade compartilhada pelo ciclo de vida dos produtos. Com a inserção dos catadores informais nas políticas públicas, com o apoio do poder público na formação de novas cooperativas (ou associações), com o fortalecimento das três associações que já existem (Guaxupé, Monte Santo de Minas e Cabo Verde) espera-se um maior desenvolvimento de mercado, produção e o consumo de produtos derivados de materiais reciclados e recicláveis na região ("força"). Tais aspectos associados ao fato da região estar em posição geográfica estratégica (entre os estados de São Paulo e Minas Gerais) com rodovias em boa qualidade, aumentam as perspectivas positivas para as questões econômicas ("força"). Além disso, o fato da maioria dos municípios serem de pequeno porte pode ser considerado uma "força", pois facilita a implantação de coleta seletiva entre outras ações, projetos e políticas públicas.

Quarenta e sete por cento (47\%) dos municípios convenentes da AMOG não possui PGIRS, o que constitui uma "fraqueza", assim cada município deveria elaborar individualmente seu próprio plano e em se tratando de municípios de porte pequeno poderá ser feito de forma simplificada. No entanto, outra possibilidade é optarem pela elaboração de um plano intermunicipal de resíduos sólidos com interesse em soluções consorciadas, pois a PNRS deixa claro que os municípios que optarem por soluções consorciadas intermunicipais para a gestão dos resíduos sólidos podem ser dispensados da elaboração do PMGIRS, desde que o plano intermunicipal preencha os requisitos estabelecidos nesta política.

Embora represente "força" a presença, na maioria dos municípios de um Conselho Municipal de Meio Ambiente (ou similar), figuram-se entre as "fraquezas" ausência de um órgão exclusivo de meio ambiente; conselhos Municipais de Resíduos Sólidos e legislações ou instrumentos de gestão ambiental sobre saneamento básico (maioria dos municípios não tem um PMSB) e de coleta seletiva de RSU. Tais "fraquezas" poderiam ser sanadas pelo poder executivo e legislativo municipais, a partir de orientações do comitê de planejamento de ações na região sobre RSU respeitando o contexto de cada localidade. A regulamentação legal e a criação de órgãos e conselhos fortalecem a fiscalização e orientam a tomada das decisões no município e consequentemente em toda a região.

Em se tratando de adoção consorciada de RSU dos municípios, a criação de um Conselho Regional de Resíduos Sólidos (CRRS) poderia assessorar todos os municípios quanto a gestão e gerenciamento dos RSU. Atualmente não existe tal conselho ("fraqueza"). O CRRS poderia orientar os municípios quanto à incidência de despesas com RSU, que atualmente é 
baixa na região ("fraqueza").

Outras ações poderiam ser implementadas: estabelecer pontes para acordos setoriais; implementação e operacionalização de sistemas de logística reversa regional; e estabelecimento de termos de compromissos junto as associações comerciais para os resíduos que sejam passíveis de logística reversa. A falta dessas ações representa "fraqueza", assim como a ausência de políticas públicas regionais de Educação Ambiental na área de RSU.

A Educação Ambiental em matéria regional, em nível de Bacia Hidrográfica e de forma consorciada entre os municípios pode ser mais adequada, uma vez que é mais razoável todos os entes públicos preservarem e conservarem os recursos naturais de forma integrada do que apenas um município isolado.

Entre as "forças", destaca-se a vocação agrícola da microrregião, por estarem inseridos na mesorregião Sul/Sudeste, área de alta produtividade agrícola, com destaque para o café (principal atividade econômica), podem fazer uso de compostos orgânicos a partir da compostagem de material orgânico presente nos RSU.

Além disso, a presença de instituições de ensino superior (públicas e privadas) na microrregião representa possibilidades de parcerias para desenvolvimento de pesquisas e inovações para a gestão e o gerenciamento e RSU, por esta razão uma "força". Outro importante fator é que muitos de seus acadêmicos são moradores da região, e a partir de projetos desenvolvidos próximos a sua realidade, espera-se uma formação crítica desses sujeitos para a superação de problemas, bem como implementações de soluções na seu próprio município, cidade e região.

A marca da região é o agronegócio, principalmente na produção e comércio de café. No entanto, pode-se dizer que falta uma marca envolvendo a sustentabilidade, ou seja, que valorize os aspectos econômicos, sociais e ambientais. Sua falta caracteriza uma "fraqueza". Neste sentido, a região, a partir de uma possível adoção consorciada para os RSU, pode avançar, reposicionar e estabelecer uma marca que agregue em seus produtos a sustentabilidade.

Uma "ameaça" é o esvaziamento do consórcio durante seu planejamento ou fase de implementação, ou seja, se um ou mais municípios deixarem o consórcio. Outra situação que pode interferir e enfraquecer a formação de um consórcio é o fato de já existir um consórcio em operação, ou sendo planejado nas proximidades. Pela falta de organização e pró-atividade de alguns gestores nas regiões, isso pode ser um estímulo para a procura de outras possibilidades. A terceirização de serviços para destinação e disposição de RSU em outras regiões ocorreu com o município de Monte Belo (convenente da AMOG), que atualmente leva seus RSU para o município de Alfenas em um aterro privado. Neste contexto, esta "ameaça" pode ser neutralizada ou ser repelida a partir da criação do consórcio intermunicipal. Além disso, a criação do consórcio é considerada uma "oportunidade", porque traz prioridades no acesso aos recursos para a gestão e o gerenciamento dos RSU e outros serviços de saneamento básico.

Outra “oportunidade”, é o fato de em Minas Gerais ter a Lei Estadual no 18.030/2009 (Lei Robin Hood), que repassa o ICMS para municípios que realizarem o tratamento e/ou disposição de resíduos sólidos com operação licenciada ou autorizada pelo órgão ambiental estadual (FEAM), aumentando sua receita.

Além disso, considera-se como "oportunidade" o fato da microrregião Sul/Sudeste de Minas Gerais estar na divisa do estado de São Paulo e com proximidade de grandes metrópoles (Belo Horizonte, MG e São Paulo, SP), bem como apresentar estradas de rodagem asfáltica em boas condições para escoamento de seus produtos, entre eles reutilizáveis e recicláveis. A possibilidade de comercialização de materiais reutilizáveis e recicláveis e disputa de mercado para outras regiões, é uma "oportunidade" pelo fortalecimento do poder de barganha das associações ou cooperativas na venda e no atendimento a indústrias. No entanto, poderá haver concorrência (“ameaças") com outras empresas e catadores autônomos, que compram os materiais recicláveis e reutilizáveis. Com as UTC cumprindo com eficiência a sua função e produzindo compostos orgânicos a partir dos materiais orgânicos que compõe a maior parte dos RSU, esta terá a "oportunidade" de atender ao crescente mercado de compostos orgânicos. 
Existem muitas instituições de ensino superior públicas e privadas no entorno desta microrregião. É uma “oportunidade" porque as ações destas instituições fortalecem a região pelo levantamento e análise de dados, bem pela sua contribuição na formação técnica e crítica desta comunidade.

Para finalizar a análise da influência do ambiente externo, cabe verificar qual será o comportamento das empresas com a possível implantação do consórcio intermunicipal de RSU. Sabe-se que a escolha para a instalação de uma empresa em uma área, entre outros fatores, está associada à análise da qualificação das pessoas, de mercado e dos serviços públicos oferecidos pelas cidades, como saneamento básico, entre eles o manejo de resíduos sólidos. Por esta razão acredita-se que sua implantação irá trazer "oportunidades" na medida que irá atrair empresas para oferecimento de serviços para o próprio consórcio e seus municípios, bem como vir para a região em razão da melhoria dos aspectos ambientais/econômicos/sociais.

\section{Considerações Finais}

Todo município é responsável pela gestão e gerenciamento dos seus RSU, no entanto há uma tendência, um direcionamento a partir da legislação ambiental, para que consórcios sejam realizados entre os municípios de uma mesma região.

A utilização da ferramenta matriz SWOT a partir de dados de gestão e gerenciamento dos RSU dos municípios da AMOG, mostrou-se como importante instrumento para o planejamento e tomada de decisões de uma microrregião para a adoção consorciada.

A análise dos ambientes interno e externo a partir da matriz SWOT evidenciou os fatores políticos, legais, tecnológicos, econômicos e socioculturais que impactam positivamente (forças e oportunidades) ou negativamente (fraquezas e ameaças) na criação do consórcio

A microrregião é constituída predominantemente por municípios de pequeno porte e a busca de soluções conjuntas (consorciadas) resultará em: menor custo em suas ações; trabalhos de Educação Ambiental em nível regional; fortalecimento das cooperativas ou de outras formas de associação de catadores de materiais reutilizáveis e recicláveis; potencialização da coleta seletiva; criação de novas Usinas de Triagem e Compostagem; minimização de risco de degradação ambiental, pela otimização do uso de áreas para a disposição final de RSU com a possibilidade de implantação de um aterro sanitário, entre outros.

O desenvolvimento desta pesquisa apresentou dificuldades na obtenção de dados secundários nas instituições públicas e privadas, ora pela falta de dados dos municípios participantes nas plataformas, ora pela descontinuidade de informações por um período de tempo, ora pela não participação dos municípios (municípios não declarantes).

Este estudo não teve a pretensão de esgotar o assunto sobre a possibilidade de criação de um consórcio intermunicipal. No entanto, contribuiu com elementos técnicos que somados a outros, como a efetiva participação da comunidade (entre os quais destaca-se os catadores de materiais reutilizáveis e recicláveis) e o diálogo entre as lideranças políticas (gestores públicos), poderão assegurar a tomada de decisões do melhor caminho para a gestão e o gerenciamento dos RSU dos municípios convenentes da AMOG.

E por fim, mas não menos importante, a possível criação do consórcio para RSU dos municípios convenentes da microrregião exige o reordenamento e redefinição de modelos existentes por um modelo mais sustentável em que o poder público (através de seus gestores), as empresas (com a finalidade lucrativa) e a comunidade (das quais destaca-se as organizações do terceiro setor) associem suas capacidades e virtudes visando o interesse coletivo do município, das cidades e da região. 


\section{Referências}

Associação Brasileira de Empresas de Limpeza Pública e Resíduos Especiais (ABRELPE). (2017). Panorama dos Resíduos Sólidos no Brasil. http://abrelpe.org.br/download-panorama-2017/.

Batista, S. (2011). O papel dos dirigentes municipais e regionais na criação e gestão dos consórcios públicos. Guia de Consórcios Públicos. Caderno 2. Brasília: Caixa Econômica Federal. https://acervo.enap.gov.br/.

Brasil. (2011) Lei Complementar no 140. Fixa normas, nos termos dos incisos III, VI e VII do caput e do parágrafo único do art. 23 da Constituição Federal, para a cooperação entre a União, os Estados, o Distrito Federal e os Municípios nas ações administrativas decorrentes do exercício da competência comum relativas à proteção das paisagens naturais notáveis, à proteção do meio ambiente, ao combate à poluição em qualquer de suas formas e à preservação das florestas, da fauna e da flora; e altera a Lei $n^{-}$6.938, de 31 de agosto de 1981. http://www.planalto.gov.br/ccivil_03/leis/LCP/Lcp140.htm.

Brasil. (2010). Decreto no 7.404. Regulamenta a Lei no 12.305, de 2 de agosto de 2010. Institui a Política Nacional de Resíduos Sólidos, cria o Comitê Interministerial da Política Nacional de Resíduos Sólidos e o Comitê Orientador para a Implantação dos Sistemas de Logística Reversa, e dá outras providências. http://www.planalto.gov.br/ccivil_03/_Ato2007-2010/2010/Decreto/D7404.htm.

Brasil. (2010a). Lei no 12.305. Institui a Política Nacional de Resíduos Sólidos; altera a Lei no 9.605, de 12 de fevereiro de 1998; e dá outras providências. http://www.planalto.gov.br/ccivil_03/_ato2007-2010/2010/lei/112305.htm.

Brasil. (2007). Lei ํㅜ 11.445. Estabelece diretrizes nacionais para o saneamento básico; altera as Leis $n^{\text {os }}$ 6.766, de 19 de dezembro de 1979, 8.036, de 11 de maio de 1990, 8.666, de 21 de junho de 1993, 8.987, de 13 de fevereiro de 1995; revoga a Lei no 6.528, de 11 de maio de 1978; e dá outras providências. http://www.planalto.gov.br/ccivil_03/_ato2007-2010/2007/lei/111445.htm.

Brasil. (2005). Lei no 11.107. Dispõe sobre normas gerais de contratação de consórcios públicos. http://www.planalto.gov.br/ccivil_03/_Ato20042006/2005/Lei/L11107.htm.

Daft, R. L. (2015). Administração. Revisão técnica Denis Forte (tradução Harue Ohara Avritcher). (2a ed.), Cengage Learning.

Empresa Brasileira de Pesquisa Agropecuária (EMBRAPA). (2015). Áreas urbanas do Brasil. http://geoinfo.cnpm.embrapa.br/layers/geonode\%3Aareas_urbanas_br_15.

Fernandes, I. G. M., Figueiredo H. M., Costa Junior H. L., Sanches S. G. \& Brasil, A. (2013). Planejamento estratégico: análise SWOT. http://www.aems.com.br/conexao/edicaoatual/Sumario-2/downloads/2013/3/1\%20(81).pdf.

Fernandez, F. A. S. (2004). O poema imperfeito: crônicas de Biologia, conservação da natureza, e seus heróis. (2a ed.), UFPR.

Fundação Estadual do Meio Ambiente (FEAM). (2016). Panorama da destinação dos resíduos sólidos urbanos no Estado de Minas Gerais em 2015. http://www.feam.br/images/stories/2016/RESIDUOS/MINAS_SEM_LIX\%C3\%95ES/Relat\%C3\%B3rio_de_Progresso_2016_-

_PANORAMA_RSU_2015_FINAL_Revisado.pdf.

Instituto Brasileiro de Geografia e Estatística (IBGE). (2018). Cidades. http://www.ibge.gov.br.

Instituto Brasileiro de Geografia e Estatística (IBGE). (2017). Pesquisa de Informações Básicas Municipais (2017). https://www.ibge.gov.br/estatisticas/sociais/protecao-social/10586-pesquisa-de-informacoes-basicas-municipais.html?=\&t=downloads.

Instituto Brasileiro de Geografia e Estatística (IBGE). (2010). Pesquisa Nacional de Saneamento Básico (2008). https://biblioteca.ibge.gov.br/visualizacao/livros/liv45351.pdf

Maximiano, A. C. A. (2011). Introdução a administração. (2a ed.), Atlas.

Memon, M. A. (2010). Integrated solid waste management based on the 3R approach. Journal of Material Cycles and Waste Management, 12(1), 30-40. https://www.academia.edu/7732952/Integrated_solid_waste_management_based_on_the_3R_approach.

Minas Gerais. (2011). Deliberação Normativa COPAM no 170. Estabelece prazos para cadastro dos Planos de Gestão Integrada de Resíduos Sólidos PGIRS pelos municípios do Estado de Minas Gerais e dá outras providências. http://www.siam.mg.gov.br/sla/download.pdf?idNorma=19114.

Minas Gerais. (2009). Lei n⿳⺈ 18.030, de 12 de janeiro de 2009. Dispõe sobre a distribuição da parcela da receita do produto da arrecadação do ICMS pertencente aos Municipios. https://www.almg.gov.br/consulte/legislacao/completa/completa-nova-min.html?tipo=LEI\&num=18030\&ano=2009.

Minas Gerais. (2001). Deliberação Normativa COPAM no 52. Reitera a convocação aos municípios com população urbana acima de 30.000 habitantes, que não cumpriram os prazos estabelecidos na DN 105/2006, a formalizarem processo de licenciamento ambiental para sistema de tratamento e/ou disposição final de resíduos sólidos urbanos e dá outras providências. http://www.siam.mg.gov.br/sla/download.pdf?idNorma=7977.

Monteiro, J. H. P. (2001). Manual de Gerenciamento Integrado de Resíduos Sólidos. IBAM.

Quintana, A. C. \& Hacon, V. (2011). O desenvolvimento do capitalismo e a crise Ambiental. O Social em Questão. Ano XIV, 25/26. http://osocialemquestao.ser.puc-rio.br/media/21_OSQ_25_26_Quintana_e_Hacon.pdf.

Rates, A. W. \& Dallacosta, G. (2018). O exercício do licenciamento ambiental municipal através de consórcios públicos - uma análise acerca da legislação aplicada. In Gonçalves, A. I. Q.; Burmann, A. \& Antunes, P. B. Direito ambiental e os 30 anos da Constituição de 1988. Thoth.

Rezende, D. A. \& Castor, B. V. J. (2006). Planejamento estratégico municipal: empreendedorismo participativo nas cidades, prefeituras e organizações públicas. (2a ed.), Brasport.

Ribeiro, D. V. \& Morelli, M. R. (2009). Resíduos Sólidos: Problemas ou Oportunidade? Interciência. 
Research, Society and Development, v. 11, n. 2, e42711225643, 2022

(CC BY 4.0) | ISSN 2525-3409 | DOI: http://dx.doi.org/10.33448/rsd-v11i2.25643

Schalch, V., Leite, W. C. A., Fernandes Júnior, J. L. \& Castro, M. C. A. A. (2002). Gestão e gerenciamento de resíduos sólidos. Universidade de São Paulo. http://www.deecc.ufc.br/Download/Gestao_de_Residuos_Solidos_PGTGA/Apostila_Gestao_e_Gerenciamento_de_RS_Schalch_et_al.pdf

Schneider, D. M., Ribeiro, W. A. \& Salomoni, D. (2013). Orientações básicas para a gestão consorciada de resíduos sólidos. Editora IABS.

Sistema Nacional de Informações sobre Saneamento (SNIS). (2017). Painel Resíduos Sólidos Urbanos: indicadores municipais. https://app.powerbi.com/view?r=eyJrIjoiNGVkYTRiZTktMGUwZS00OWFiLTgwNWYtNGQ3Y2JIZmJhYzFiIiwidCI6IjJiMjY2ZmE5LTNmOTMtNGJiMS 05ODMwLTYzNDY3NTJmMDNINCIsImMiOjF9.

Tchobanoglous, G., Theisen, H. \& Vigil, S. (1993). Integrated solid waste management engineering principles and management issues. McGraw-Hill, Singapore.

Vilhena, A. (2018). Lixo municipal: manual de gerenciamento integrado.(4a ed.), CEMPRE. http://cempre.org.br/upload/Lixo_Municipal_2018.pdf.

Wright, P. L., Kroll, M. J. \& Parnell, J. (2010). Administração estratégica: conceitos (tradução Celso A. Rimoli, Lenita R. Esteves). Atlas. 